\title{
MINERAL RESOURCES DEVELOPMENT AND MANAGEMENT STRATEGY IN SIERRA LEONE
}

\author{
KOROMA David Kanume ${ }^{1,{ }^{*}}$, WANG Yujie ${ }^{2}$ and KOROMA Cintia Betiza ${ }^{3}$ \\ 1, 2Department of Mining Engineering, School of Natural Resources and Environmental Engineering, \\ Wuhan University of Technology, Wuhan, P. R. China, 430070 \\ 1,3 Lower Registry, Registry, \\ Milton Margai College of Education and Technology, \\ Njala University, Goderich Campus, Freetown, Sierra Leone \\ 1* dskkoroma@hotmail.com, ${ }^{2} 814139036 @ q q . c o m$ and 3 betizacv@hotmail.com
}

\begin{abstract}
Mineral resources management has today become one of the key factors in the extractive industry which has gotten a lot of attention from the populace and government of resources rich countries, thus its exploration and production must also pursue a sustainable mode. Based on the current management of mineral resources in Sierra Leone, this research will attempt to identify the problems and challenges like the unfavorable historical manner of extractive governance which has impeded growth and development. An immediate requirement for consistent legal, financial and institutional structures will be analyzed in other to improve the process of managing the resources, the economy and accountability of revenue earned from the extractive sector in Sierra Leone.
\end{abstract}

Keywords: Management, Development, Extractive Industry, Mineral resources, Sierra Leone.

\section{Introduction}

With rising development in extractive industries and changing prices of minerals worldwide, we are posed to reform the institutional structures, improve policy management and implementation of those policies on paper and on ground. Sierra Leone has seen a devastating civil war and has suffered drastically from it economically, socially and other wise. A country very rich with abundant mineral resources should be one of the richest or developed countries in the world.

It is considerable that Sierra Leone is one of the crowning jewels of Africa due to its abundance of natural resources which positively impacts the economic stability and growth of the country. It is, therefore, imperative to protect and manage the mineral resources by government, agencies, and the people as well.

Most times in resource rich countries, the symmetric distribution of benefits arising from economic activity created by the extractive industry suggest that the industry operates as an enclave in the host country with limited links to the wider economy. This gap between the profits of operating companies and local economic benefits is likely to expand if resource owners do not put appropriate policies in place to capture, retain value created from the industry and make them the key focus as I tend to showcase in my research. Revenues received can be utilized positively to improve the economy and standard of living of the larger populace [1].

We will also see neoliberalism eating the fabric of sub-Sahara Africa as of early days and has consequently increased the power and influence of companies [2].

\subsection{Present Status of the Large-Scale Mining Sector}

The potential of the large-scale mining sector to generate significant revenues for GoSL in the short and medium term has deteriorated significantly in the past few years [3]. 


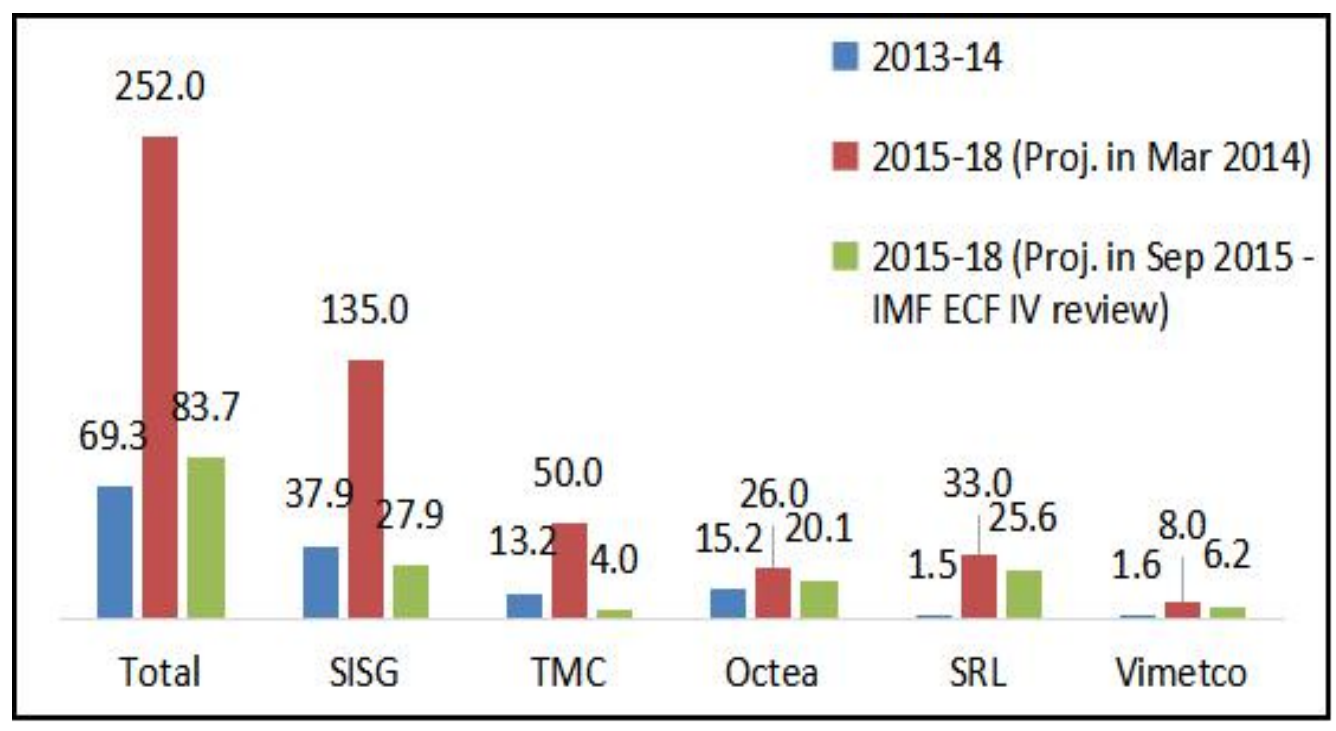

Figure 1, Royalty collection from the large-scale mining sector (US\$ millions). Sources: [4]

This note a chart of the current status of each of the large-scale mining projects, and the revenue GoSL collected and was expected to collect during the period. But dew to the unforeseen situation of the epidemic, closure of mining companies and mismanagement of funds the full expected outcome was not reached. We are of the impression that after the extractive industry gains momentum, we will see a boost of the revenues own to GoSL [5].

In addition to making some recommendations at the ending part, the Revenue and Tax Policy Division has also conducted a comprehensive risk assessment of mining revenue administration. This assessment will identify the actions required by GoSL to ensure that, though the revenue potential of the sector has deteriorated, it is minimizing the leakages and is putting the systems and processes in place for it to fully benefit if and when the sector recovers [17].

\section{Environmental Governance}

In order to provide an accurate and reliable basis for the economic accounting of national resources and the rational exploration, exploitation ,utilization and conservation of resources, the government of resource rich countries should create a new classificatory criteria stressing that annual assessment of mineral resources reserves should be conducted. A dynamic database that promptly and accurately reflect the economy and the consumption of resources reserves must be established, and the dynamic management of resources reserves should be implemented [6].

Primary to EG in the extractive industries is the EIA, similar in legislation and implementing institutions [7]. The most immediate purpose of the EIA is for mining companies to supply decision-makers with an idea of the likely environmental and social consequences of their operations, as well as the strategies they intend to employ or to address and manage these consequences. This is with the aim of ensuring that development proceeds in an acceptable manner and contribute towards a more sustainable type of development.

But despite this growth in the global EG movement by way of new treaties, and a more participatory and active system, environmental degradation continues at an alarming rate. Mining-induced environmental and social problems continue to pervade in African countries that have embraced EG, a case in point being Sierra Leone. As mentioned, a number of scholars have argued that at the crux of the ineffectiveness of the EG agenda is the neoliberal ideology that underpins it [2].

\subsection{Environmental Governance in Sierra Leone}

After the civil war, mining has been the center piece of development strategy in Sierra Leone.

In a bid to revive its economy, Sierra Leone has adopted a host of natural resource governance strategies, one of which is the EG agenda for its mining sector. In the early years of post-war reconstruction in the country, the government requested assistance from donors to develop its mineral 
policy for a growing mining industry. The World Bank carried out a Strategic Environmental and Social Assessment (SESA) of the mining sector, calling for new policies and strengthened institutions and governance for mining [8]. These recommendations would inform and greatly influence policy dialogue.

The main component of the EG agenda for mining is the EIA. To obtain the environmental license, mining companies (large-scale and small-scale) must conduct an EIA; make adequate proposals to mitigate and/or manage impacts; public disclosure of the details of potential impacts; and present a community development action plan. Companies are also required to propose plans for mine closure and compensation, and when necessary, details of a resettlement management plan. These must be documented in a report which forms the basis of the application for an environmental license. Once EPA officials, including its Board of Directors, are satisfied that the company has sufficiently fulfilled its obligations according to the law, an environmental license is issued $[9,10,11]$.

In early 2011, parliament passed a fee schedule that sets out a point system to quantify the environmental foot print of a project and to determine what sort of EIA is needed. This fee system allows the EPA to recoup its costs from the licensing process and subsequent monitoring $[8,10]$.

Another major component of Sierra Leone's mining EG framework is the MMA. This legislation underwent review for several years, including significant technical inputs by Adam Smith International. The MMA lays out the legal framework for mining in Sierra Leone, discusses the required EIA process and contains specific details on the responsibilities, duties and obligations of companies and the Ministry of Mineral Resources (MMR). The MMA is administered by the MMR. This Act mandates a common framework for minerals agreements with the government [12]. Other legislation, such as "The Environmental and Social Regulation for The Minerals Sector, 2011", also provides details on the responsibilities, duties and obligations of companies, the MMR and the EPA [10].

\section{Discussion and Conclusion}

\subsection{Major Contribution}

Expansion of the extractive sector in Sierra Leone especially following the recent rediscovery of iron-ore mines has initiated a process of structural transformation in the economy. The country is experiencing today some development in its productivity from the primary sector to the mining and extractive activities. As a result, the mining sector became the main driver of economic growth leading to an unprecedented high growth. This should in principle, be accompanied by structural transformation, and defined as the transfer of workers from activities and sectors with low average labor productivity to those with high average labor productivity, thus contributing to an increase in average labor productivity for the overall economy, increasing diversification and sophistication of exports. Likewise, apprehending these impacts and their dynamics are of critical importance in the design of appropriate regulations [13].

The goal is to use the natural resource endowments to develop a competitive local supply industry that, through employment creation, value addition, technology and knowledge transfer; they can foster broad-based sustainable development. In other words, justifying this research will be to develop conditions to create production (forward and backward) and horizontal links between the extractive industries and the host country's local economy. This goal is commonly referred to as local content $[1,14]$. The Sierra Leone's extractive sector's contribution to GDP in 2013 was about 23\% but is expected to slow to $6.0 \%$ in 2014 as an effect of Ebola (against an $11.3 \%$ projection) and it is projected to go as low as $-2.5 \%$ in 2015 before reaching $2.8 \%$ in 2016 [15].

In 2004, the Sierra Leone Truth and Reconciliation Commission (SLTRC) reported that the central cause of the civil war had been the endemic greed, corruption and nepotism of political elites. To prevent another disaster, a proper management and accountability system for handling the mining industry and mineral resources has to be developed both on paper and on ground [16].

We will not be able to conclude without mentioning Neoliberalism eating the fabric of sub-Sahara Africa. Neoliberalism gained momentum in the 1980s, with the widespread adoption of Structural Adjustment Programs (SAPs), implemented under the auspices of the World Bank and International 
Monetary Funds. The Bretton Woods Institutions called for deregulation of the state and its powers, a fall in government expenditure, privatization and liberalization to promote market-enabling foreign direct investment in struggling economies, especially in sub-Saharan Africa [2].

\subsection{Mining Industry, Policies and Productivity.}

Sierra Leone currently has 5 Large Scale Mining Companies, and 4 others at an advanced stage of commencing large scale gold and iron-ore mining operations respectively; 217 Exploration Companies; 6 Small Scale Mining Companies; and over 200,000 people engaged in Artisanal mining operations all around the country. The Ebola outbreak did not significantly affect the operations of the five large scale mining companies. However, some of the exploration companies suspended operations following departure of their expatriate staff resulting from the Ebola outbreak [17].

Policies regarding well-management of mining industry should be done alongside a broader focus for the economy's development, and greater efforts should be done to expand the manufacturing and service sector, which currently only contribute $12 \%$ to the GDP. Sierra Leone produces raw diamonds but gem-quality diamonds are manufactured in developed countries like Belgium. For example, the government of Sierra Leone can provide greater tax incentives for investors to conduct businesses and invest in Sierra Leone, and also to facilitate the transfer of technology and skills to the native workers. One recent example is the Gemstone School Sierra Leone, which was established as an institution to improve diamond polishing, cutting and jewelry-manufacturing skills to boost job-training and employment opportunities locally and to attract overseas investors. More efforts from the government and Multi-National Corporations can hence be done in the future to build more diamond-processing facilities and plants in Sierra Leone to boost the diamond mining industry [17, 18].

As we conclude, we have seen that extractive industry may raise government revenues mainly through: direct ownership (with state-owned companies or joint ventures), taxation (corporate income, value added, and other specific taxes) and royalties and/or payments under contractual arrangements (like concessions or production share agreements in the oil industry).

These revenues have a positive impact as a source to finance public infrastructures, human capital investments (education, health) or to support the development of other economic sectors.

We will explain briefly the effect of ebola on the five main mining companies. Tonkolili Iron Ore and London Mining/Timis Mining Corp. were expected to hit their targets if conditions remain stable after the emergency of ebola. This obviously has the potential to change if operations are scaled back from any further escalations resulting in a prolonged cessation of fundamental mining activities/ processes. Sierra Minerals Holdings production was expected to increase over 2\%. Sierra Rutile Limited was expected to decrease production by close to $5 \%$ for Natural Rutile. Ilmenite and Zircon production are expected to increase considerably. Production at Octea mining was expected to decrease by $10 \%$ for the remaining part of 2015 [17].

Another solution: the government of Sierra Leone should listen to the local resident's needs and concerns, revise the 2009 Mines and Mineral Acts and enforce the labor laws against the mistreatment of workers at the mines.

On the other hand, the mining companies should create more attractive and well-paying jobs for Sierra Leoneans; share their corporate profits by investing more than $10 \%$ in communities of operations and beyond, and transfer its technology to Sierra Leoneans so as to enable them to have access to more paying jobs. This could be a win-win situation for everyone and a way out for a fluid and dangerous sector. It could also be a better way out for all the parties affected and the best hope to avert poverty and social unrest.

In achieving some of the objectives of EITI like improving the process of management, creating more attractive environment for investors, improving revenue collection system, building trust between citizens, government and companies, and creating an avenue for group discussion of major issues amongst all parties, Sierra Leone now stands again on the verge of an unprecedented period of economic growth, driven primarily by revenues from mining companies [19]. 


\section{References}

[1] C. Sigain and L. Garcia: Extractive Industries, Optimizing Value Retention in Host Countries, New York and Geneva, 2012. Information on http://unctadxiii.org (2012).

[2] Mason and N. Hannah: Environmental governance in Sierra Leone' s mining sector: A critical analysis. Resources Policy, 41, p. 152-159. (2014).

[3] The Mines and Minerals Act 2009: Sierra Leone gazette, Vol. CXLI, No. 3. (2010). Information on http://www.sierralii.org/node/1295.

[4] E. Rugraff, D. Sanchez- Ancochea and A. Sumner: Transnational Corporations and Development Policy, Springer Nature, Vol. XIII, p. 321. (2009).

[5] Ministry of Finance and Economic Development, Sierra Leone. MoFED, (2015).

[6] L. Jin-ping, H. Yang and T. Wang: Mineral Resources Development Strategy in China-Macro-Management, International Conference on Management and Service Science, ISBN: 978-1-4244-5325-2. (2010).

[7] World Forum on Science and Democracy. Belem, (2009).

[8] E. T. Ndomahina: Environmental and social impact assessment study. Final report (2008).

[9] M.E. Brown, F. Tondel, B. Stabler, T. Essam and K. Leonard: Country and regional staple food price indices for improved identification of food insecurity. Global environment change, JGEC995, p. 11. (2012).

[10] Government of Sierra Leone, (2008, 2009, 2011).

[11] R. Maconachie: Diamonds, governance and 'local' development in post-conflict Sierra Leone: Lessons for artisanal and small-scale mining in sub-Saharan Africa, Resources Policy, 34 (1-2), pp. 71-79. (2009).

[12] United Nations Environment Programme: Environment for development, Annual report. (2010).

[13] N. Guy- Blaise: Agricultural water management. African development Bank Group, (2011).

[14] 2nd International Conference CSR, sustainability, ethics and governance. Information on CSR Sustainability Ethics \& Governance (2015).

[15] www.africaneconomicoutlook.org/po/notas-paises/west-africa/sierra-leone.

[16] A. Lilian and D. R. Steven: The Development of Institutions of Human Rights, Springer Nature, ISBN: 978-1-4039-7653-6 (Print) (2010).

[17] P. Bangura: National Mineral Agency report, unpublished. (2015).

[18] Mining in Sierra Leone: Information on http://en.wikipedia.org/wiki/Mining_in_Sierra_Leone.

[19] Sierra Leone Extractive Industry. (2015). 